\title{
Otohematoma bilateral em ovino: relato de caso
}

Ingrid Letty Prado, Anna Maria Zimmermann, Katiucha RJ Lopes Lera, Bruno Schuh, Eduardo Zache, Geane Maciel Pagliosa

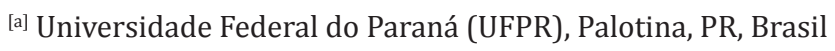

*Autor correspondente

e-mail: ingridletty@gmail.com

\section{Resumo}

O otohematoma é uma afecção caracterizada pelo acúmulo de sangue entre a pele e a cartilagem internas do pavilhão auricular, decorrente de traumas diretos, movimentos bruscos da cabeça devido à dor ou prurido ocasionados por inflamações, ectoparasitas, corpos estranhos, tumores e pólipos no canal auditivo. É mais comum em pequenos animais, mas já diagnosticada em ovinos devido a ácaros e por dermatite alérgica por picada de insetos.Este trabalho relata o caso de otohematoma bilateral em um ovino macho, de três anos de idade, que foi encaminhado ao Setor de Grandes Animais do Hospital Veterinária da Universidade Federal do Paraná - Setor Palotina, com histórico de aumento do volume pruriginoso em pavilhão auricular esquerdo (PVE) com 15 dias de evolução, que foi drenado com agulha não estéril sete dias antes do atendimento. No exame clínico, observou-se aumento de volume no PVE de consistência flutuante e crosta sanguinolenta central de odor fétido na região interna da orelha. No meato acústico externo foi realizado swab para pesquisa de ectoparasitas. No aumento de volume foi realizada punção com material estéril após antissepsia local retirando-se líquido serosanguinolento de odor fétido, o qual foi enviado para cultura.Não foram observados ectoparasitas, e a análise microbiológica isolou Staphylococcus sp. e Escherichia coli. 0 tratamento adotado foi drenagem cirúrgica do otohematoma, com tratamento da ferida por segunda intenção, a qual apresentava bordas viáveis e tecido de granulação saudável após 14 dias. Porém, desenvolveu-se otohematoma no pavilhão auricular direito (PVD), que foi tratado cirurgicamente com o paciente sob anestesia geral, mediante incisão elíptica na face medial do PVD, onde se drenou líquido serosanguinolento aplicando-se suturas adjacentes e paralelas à abertura cutânea em padrão de Wolff captonado, com fio de náilon, incorporando a pele das faces interna e externa e a cartilagem da orelha,em toda a extensão da mesma. Após 10 dias ocorreu deiscência de sutura e a ferida foi tratada por segunda intenção. Após as 
duas intervenções, foi realizado tratamento sistêmico com ceftiofur e flunixim meglumine por cinco dias. Houve o enrugamento da cartilagem auricular de ambas as orelhas. Após três meses de internamento, o animal recebeu alta, com cicatrização cutânea completa. No ovino deste relato não foi identificada a causa do primeiro otohematoma, mas suspeita-se ser devido ao movimento da cabeça durante a cicatrização do PVE a ocorrência da mesma enfermidade na orelha contralateral. 0 crescimento bacteriano no líquido do PVE provavelmente foi decorrente da contaminação pela punção não estéril realizada pelo proprietário. Embora tendo havido o enrugamento da cartilagem como sequela, o ovino deste relato voltou à atividade de reprodutor, onde foi mantido por mais quatro anos sem nenhum relato de comprometimento da saúde ou outra alteração auricular. 0 tratamento preconizado, embora prolongado, foi eficaz na cura do paciente. 